\title{
Los nombres del OPPIDUM de Monte Bernorio (Villarén, Palencia). Las denOMinaCiones dE loS OPPIDA CÉLTICOS DEL NORTE DE LA PENÍNSULA IBÉRICA: ESTRUCTURA POLÍTICA E IDENTIDAD ÉTNICA
}

Jesús F. Torres Martínez Universidad Complutense de Madrid

MANUel FernándeZ-GöTZ University of Edinburgh

Juan Manuel Sobremazas

Instituto Monte Bernorio de Estudios de la Antigüedad del Cantábrico (IMBEAC)

Recibido: $11 / 03 / 2016$

Revisado: 07/06/2016
Aceptado: $13 / 06 / 2016$

Publicado: 30/06/2016

\section{RESUMEN}

El objetivo de este trabajo es abordar el problema del nombre que podía haber recibido el oppidum de Monte Bernorio (Palencia). La cuestión de las denominaciones de los oppida y de los grupos étnicos que habitaban los distintos territorios se pone en relación con casos similares del norte de la Península Ibérica y del occidente de Europa. Finalmente, en relación con la cuestión de los nombres de los oppida se aborda también la problemática de los etnónimos de los pueblos célticos en relación con su organización social y estructuras políticas.

\section{ABSTRACT}

This paper discusses the problem of identifying the name by which the oppidum of Monte Bernorio (Palencia) was known. The denomination of the oppida and of the communities that inhabited them is compared with similar cases from Iberia and Western Europe. Finally, we analyse the question of the ethnic names of the so-called Celtic populations in relation to their social organisation and political structure.
Palabras Clave

monte bernorio; cantábrico; edad del hierro; oppida; etnónimos.

\section{KEYWORDS}

monte bernorio; cantabrian region; iron age; oppida; ethnic names.

ketxutorres@yahoo.com

m.fernandez-gotz@ed.ac.uk 


\section{El OPPIDUM DE MONTE BERNORIO}

El oppidum de Monte Bernorio está situado en el municipio de Pomar de Valdivia (Palencia), accediéndose a él por una vía pecuaria que arranca en el pueblo de Villarén. El yacimiento se sitúa en la parte superior de la montaña del Bernorio, ubicada en la parte central de la Cordillera Cantábrica, en el sector oriental del conjunto de relieves que se denomina Montaña Palentina. Se trata de una amplia meseta rodeada de escarpes, pequeños acantilados y laderas muy abruptas que lo convierten en un espacio con unas buenas condiciones defensivas naturales. Se proyecta sobre una intersección de vías de comunicación naturales: la vía que cruza y une ambas vertientes de la Cordillera Cantábrica por su lado central; la vía que recorre el piedemonte cantábrico en el eje este-oeste por su fachada meridional; las vías secundarias que permiten acceder a las cabeceras de las cuencas de los ríos Ebro y Pisuerga así como las vías de acceso a las brañas situadas en la Sierra Hijar, recurso de enorme importancia para las sociedades agro-ganaderas de la Protohistoria.
Con estas destacadas condiciones naturales la montaña del Bernorio ha sido un importante referente geográfico para los grupos humanos a lo largo de la Historia. Se han localizado materiales de época neolítica en las proximidades del Bernorio, aunque sin que se conozcan todavía evidencias de una ocupación estable en este periodo. Los yacimientos arqueológicos localizados en la montaña indican que la ocupación estable del entorno se inició en el Calcolítico, desarrollándose de forma progresiva hasta alcanzar su óptimo en la Edad del Hierro (Torres Martínez, 2007; Torres Martínez et alii, 2011; Torres Martínez, 2012; Torres Martínez et alii, 2012a; y Torres Martínez et alii, 2012b.).

Los materiales arqueológicos localizados en los niveles más profundos de la cima de la montaña indican que el primer establecimiento permanente se iniciaría en el final de la Edad del Bronce (900-800 a.C. aprox.). Estos materiales se han localizado en el Área 1, en la acrópolis, y el Área 3, en la ladera sur (dos de las tres zonas excavadas). Esto podría indicar que en este momento existía bien una ocu-

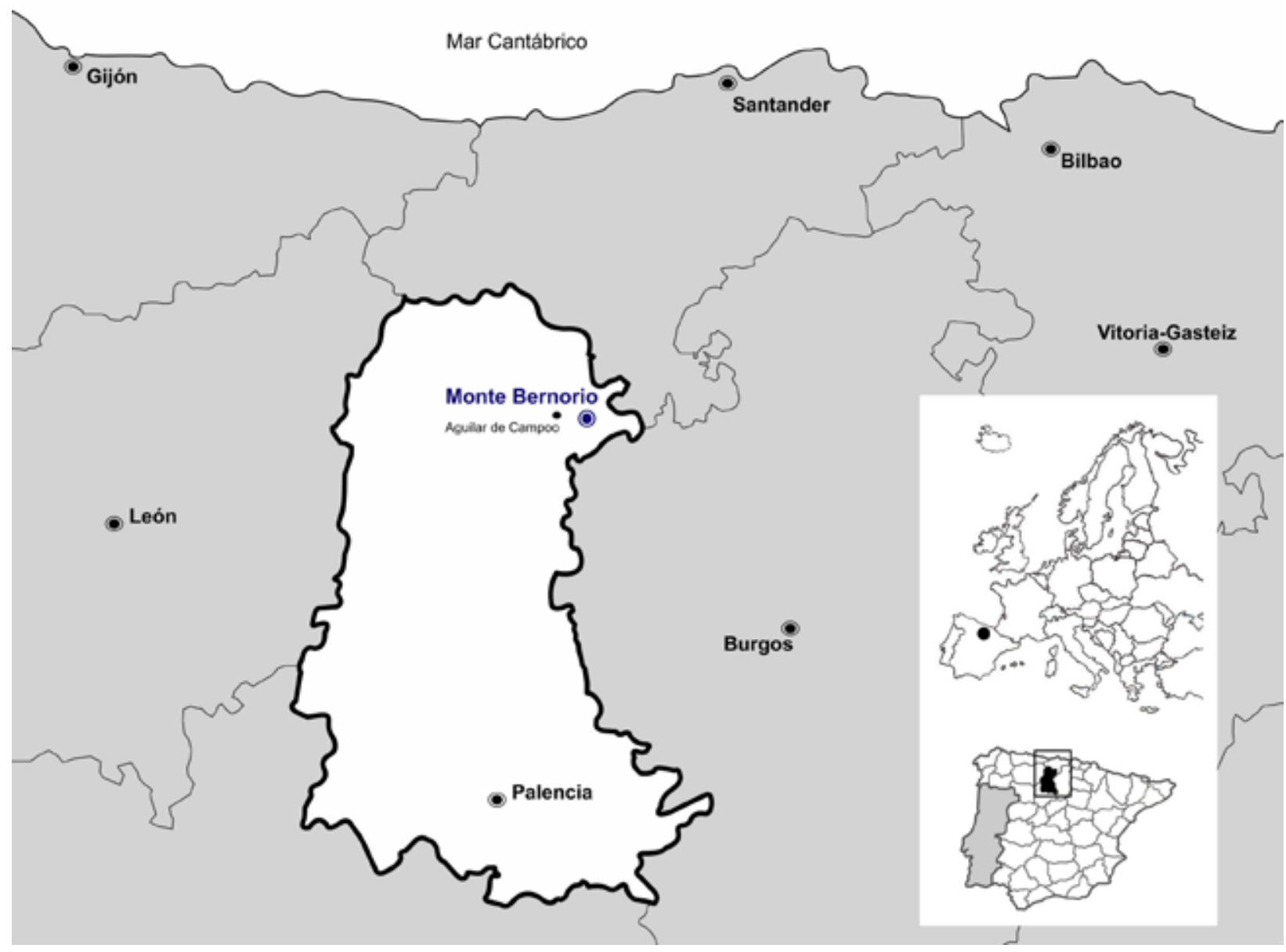


pación muy extensa o bien una ocupación discontinua, como una serie de aldeas dispersas en distintas áreas de la cima del Bernorio. En todo caso, a partir del siglo VIII a.C. este núcleo se desarrolló hasta adquirir grandes proporciones y se transformó en todo un referente geográfico y territorial (Torres Martínez, 2012, 7-12, 16-18).

Al final de la Edad del Hierro (siglos III-I a.C.) el núcleo de Monte Bernorio es un oppidum similar a otros del mismo tipo repartidos por otras áreas del norte peninsular y de todo el ámbito central y occidental de Europa (Collis 1984; Fichtl, 2005, 2012 y Fernández Götz, 2013; 2014b). El núcleo estaba protegido por un potente sistema defensivo con muralla y foso, puertas fortificadas y campo atrincherado a base de multivallado. Dentro del perímetro amurallado la extensión del núcleo es de unas 28 ha. Y con el campo atrincherado compren-

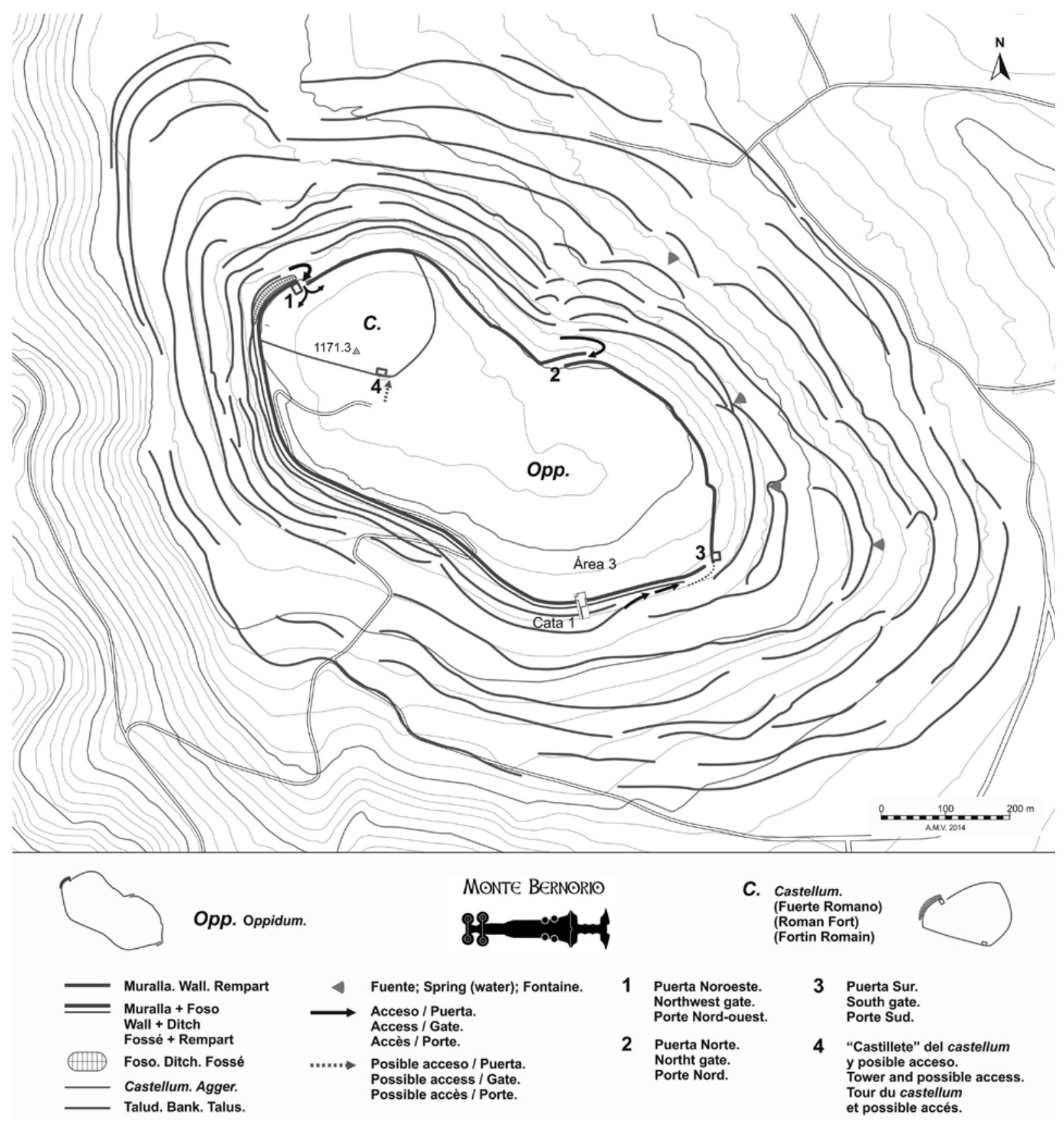


de unas 90 ha. Su estratégica ubicación favoreció tanto su crecimiento urbano como su importante proyección territorial y política. Todo indica que al final de la Edad del Hierro (siglos III-I a.C.) actuaba como núcleo principal de un amplio territorio. Pero además debemos considerar la posibilidad de que actuara también como un lugar central de varias comunidades pertenecientes a una misma etnia (un primum oppidum u oppidum capitale), en este caso la de los cántabros. En este sentido Monte Bernorio es un núcleo similar a otros del mismo tipo dentro del contexto cultural de las culturas del ámbito céltico del norte de la Península Ibérica y de la fachada atlántica Europa occidental (Fernández Götz, 2014a.).

El final del oppidum del Bernorio viene determinado por la guerra de expansión que Roma desarrolla en esta zona a finales del siglo I a.C. Las evidencias arqueológicas indican que el núcleo fue atacado y destruido por las fuerzas romanas que bajo el mando del emperador Octavio Augusto atacaron la zona meridional del territorio de los cántabros. Todo apunta a que el ataque sobre el oppidum se desencadenó desde el vecino campamento romano de El Castillejo (Pomar de Valdivia). Se trata de un campamento romano de campaña (castra aesti$v a$ ), fechado a finales del siglo I a.C., en el contexto de las Guerras Cántabras (Peralta, 2003, 280-282, 301-303 y Figs. 147 y 148; 2004a, 33-34; 2004b, 101, 115 y Fig. 12; 2006, 535-539.). Después de la destrucción del Bernorio su valor estratégico hizo que fuera ocupado de nuevo, esta vez por un castellum romano que sirvió para controlar los pasos naturales y el montañoso territorio durante, al menos, varias décadas.

Desde el punto de vista arqueológico, el Bernorio es conocido a partir de las excavaciones desarrolladas por Romualdo Moro, capataz de Excavaciones Arqueológicas del Marqués de Comillas, en 1890. Moro excavó en la acrópolis del núcleo y tal vez en otras áreas, pero los resultados allí obtenidos le hicieron desistir. Posteriormente excavó en lo que hoy se conoce como la necrópolis del Bernorio, donde encontró los puñales "tipo Monte Bernorio" y otros materiales que formaban parte de los ajuares depositados en los túmulos funerarios (Moro, 1891; Navarro, 1939, 164-172). Estos materiales de la colección Bernorio se hicieron célebres por su originalidad y por la espectacularidad de sus diseños. Fueron estudiados a lo largo de la primera mitad del siglo XX por investigadores de la Protohistoria española de la talla de J. Cabré Aguiló, A. Schulten, P. M. Artiñano, R. Navarro y W. Schüle (Cabré, 1931, 222-241, fig. 4 y lam. I, IX, X, XI; Cabré y Cabré, 1933; Navarro, 1939, 164-172; Schüle, 1969; Barril, 1995a, 408, 1995b, 1999, 46-51).

Dada su estratégica situación, Monte Bernorio volvió a ser el escenario de violentos combates durante los primeros momentos de la Guerra Civil Española (1936-1937), dentro de las operaciones militares del denominado Frente Norte. El yacimiento sufrió trabajos de fortificación con la construcción de trincheras, bunkers y barracones que pusieron al descubierto numerosos metros de muralla del oppidum y una gran cantidad de materiales arqueológicos (Torres, Martínez y Domínguez, 2008; Ruiz Alonso, 2013, 41-42, 56-65, 129-241; Román, 2013).

Una vez finalizado el conflicto, en 1943, comienzan las primeras intervenciones arqueológicas verdaderamente científicas que fueron dirigidas por J. San Valero Aparisi y que se desarrollaron durante los años 1943, 1944 y 1959, extendiéndose por diversas áreas del oppidum. Sin embargo, pese a que el Bernorio era un referente arqueológico, tras la campaña de 1959 se abandonaron las excavaciones y no se volvió a intervenir en el yacimiento hasta el inicio del actual proyecto, en el año 2004 (San Valero 1944, 1960; Torres-Martínez, 2007, 80-81).

Este nuevo proyecto se lleva a cabo actualmente en el marco de un convenio de colaboración entre el Departamento de Prehistoria de la Universidad Complutense de Madrid y la School of History, Classics and Archaeology de la University of Edinburgh, bajo la dirección conjunta de J. F. Torres-Martínez y M. Fernández-Götz. Forman parte del equipo investigador profesionales especialistas en la Arqueología del Cantábrico central, además de arqueólogos e investigadores profesionales vinculados al proyecto y licenciados y estudiantes de la Universidad Complutense de Madrid, del Instituto Monte Bernorio de Estudios de la Antigüedad del Cantábrico (IMBEAC) y de la School of History, Classics and Archaeology de la Universidad de Edimburgo, además de otras universidades nacionales y extranjeras. También ha colaborado un equipo del Institut für Archäologische Wissenschaften de la Universidad de Frankfurt am Main, dirigido por el Prof. Felix Teichner, desarrollando dos campañas de prospecciones de teledetección electromagnética de estructuras en el subsuelo del yacimiento. 
Las campañas de investigación arqueológica desarrolladas desde el año 2004 han permitido comprender tanto la estructura del núcleo y sus estructuras defensivas como una parte de su trama urbana. También han servido para recuperar, en el interior del núcleo, abundantes materiales arqueológicos de la Primera y Segunda Edad del Hierro (s. IX a.C. al I d.C.). Las excavaciones realizadas en una de las áreas de la extensa zona de necrópolis han dado como resultado la localización de estructuras funerarias y de restos de cultura material. Son muy significativos, además, los restos de material militar de la Segunda Edad del Hierro, tanto indígena como romano y los indicadores de, al menos, un nivel de destrucción relacionado con el fin del núcleo, a finales del siglo I a.C.( Torres Martínez, 2007, 93-98; Torres Martínez et alii,2011; Torres Martínez et alii 2012 y 2013).

Las investigaciones en curso están permitiendo comprender la importancia que el oppidum de Monte Bernorio llegó a tener en el contexto del sector meridional del territorio de los cántabros. Las evidencias de un final violento del núcleo en relación con la Guerras Cántabras pueden permitir relacionar esta ciudad fortificada con alguno de los oppida mencionados en las fuentes clásicas sobre las primeras fases de este conflicto.

\section{Las Posibles denominaciones del OPPIDUM DE} MONTE BERNORIO A PARTIR DE LOS TESTIMONIOS DE LAS FUENTES

Es muy posible que el oppidum de monte Bernorio haya sido mencionado en las obras que narran las operaciones militares en la primera fase de la conquista del territorio de los cántabros. Esto es así, como ya hemos mencionado, por su ubicación geográfica, por su estratégica posición de control sobre los pasos de la Cordillera Cantábrica en su sector central y por las evidencias que suponen los materiales recuperados en su interior. En este sentido, los pasajes que más se ajustan a este perfil son los de Dión Casio en su Historia Romanorum (LII, 25, 7), Lucio Anneo Floro en su Epitome de Gestis Romanorum (II, 33, 49) y Paulo Orosio en su Historia Adversos Paganos (VI, 21,5) que recogen la toma de una gran ciudad fortificada que recibe distintas denominaciones aunque, con toda probabilidad, sea el mismo núcleo. Todos estos son resúmenes de la fuente principal sobre este conflicto, la obra de Tito Livio Ab Vrbe Condita, perdida en lo que se refiere a los libros que conciernen a este episodio. En ella, desde el libro 135, se tratarían, al parecer, los acontecimientos de la guerra con todo detalle (González, 1977, 199-202, 1997, 140-144, 1999b, 147-151, 166-167).

\section{A. Floro, Epitome, libri XII, II, 33, 49-50}

"Primuma dversus Cantabros sub moenibus Bergidae proeliatum, hincstat im fuga in eminentissimum Vindium montem, quo mariaprius Oceani quam arma Romana ascensura ese crediderant; tertio Aracelium oppidum magna vi repugnat, captumtamen postremo fuit Medulli montis obsidio".

"Primeramente se luchó contra los cántabros bajo las murallas de Bérgida, de aquí huyeron al elevadísimo monte Vindio, allí creían que antes llegarían las aguas del océano que las armas romanas. En tercer lugar resiste con grandes fuerzas la ciudad de Aracelio. No obstante fue tomada. Finalmente se produjo el asedio del monte Medulio".

P. Orosio, Historia Adversos Paganos libri VII, VI, 21, 5-6

"Tuncdemum Cantabri sub moenibus Atticae maximo congress i bello et victim Vinnium montem naturatutissimum confugerunt, ubi obsidionis fame ad extremum paene consumptisunt. Racilium deinde oppidum magna vi ac diure pugnans postremo captum ac dirutum est. Praetere aulteriores Gallaeciae partes, quae montibus silvisque consitaeOceano terminantur (Antistius et Firmius, legati) magnis gravibusque belli sperdomuerunt, nam et Medullium montem Minio flumine inminentem (in quo se magna multitude hominum tuebatur per quindecimmilia passum fossa circumsaeptum obsidione) cinxerunt".

"Entonces, por fin, los cántabros se reunieron bajo las murallas de Áttica para una gran batalla $y$, vencidos, se refugiaron en el monte Vinnio, inexpugnable por naturaleza, donde asediados por el hambre perecieron casi hasta el último. Tomóse después, y se arrasó, la ciudad de Racilio, que resistió con gran empeño y por mucho tiempo. Además, las zonas ulteriores de Gallaecia, sembradas de montañas y bosques, que lindan con el Océano, las sojuzgaron con grandes y penosas guerras. Pues cercaron el monte Medulio, que se levanta sobre el río Minio”.

Con respecto a estos pasajes y su posible vinculación con el núcleo de Monte Bernorio, es necesario valorar su estratégica posición en el flanco sur 


\begin{tabular}{|c|c|}
\hline ETNIA & CANTABRI \\
\hline SUBETNIA O CIUITATES & VELLICI \\
\hline DENOMINACIÓN DEL OPPIDUM & BERGIDA, VELLICA \\
\hline YACIMIENTO ARQUEOLÓGICO & MONTE BERNORIO \\
\hline
\end{tabular}

del territorio de los cántabros. Por ese motivo, el oppidum de Bernorio era un núcleo que debía ser conquistado por las fuerzas romanas en su avance durante la fase inicial del Bellum Cantabricum. Es muy posible que fuera el propio emperador Augusto el que dirigiera estas operaciones ya que, según las fuentes, la primera fase de la campaña del año 26 a.C. fue dirigida personalmente por él (Syme, 1989, 418-420; González Echegaray, 1997, 144-151, 1999b, 147-151; Peralta, 2003, 315).

J. González Echegaray sitúa el núcleo de Velli$c a$ y el escenario de la batalla citada en los testimonios de Orosio (VI, 21, 5) y Floro (II, 33, 49), que denomina a esta población como Bergida, en el entorno de Mave (Palencia), junto al río Pisuerga. Se trata de una llanura en las inmediaciones del oppidum de Monte Cildá (Olleros de Pisuerga, Palencia), situado a pocos kilómetros del Bernorio. Este autor explica cómo tras este suceso se produjo el asedio a Aracillum o Racilium, un oppidum que consiguió resistir un asedio prolongado hasta que cayó y fue destruido (González Echegaray, 1999b, 166-167). Este pasaje de la guerra podría ser interpretado como una equivalencia probable con un oppidum como el de Monte Bernorio, bien fortificado y situado un poco más al norte en el avance hacia el paso de la Cordillera Cantábrica. Pero el estado actual de las investigaciones y las indicaciones de algunos documentos como el denominado Itinerario de Barro no permiten aceptar como probable esta hipótesis (Blázquez, 1920, 102, 106; García Bellido, 1975, 554-556; Fernández Ochoa et alii, 2012, 161).

Por su parte, E. Peralta considera que el pasaje de la toma de Vellica (también Bergida o Attica) recogido por Dión Casio (LII, 25, 7), Floro (II, 33, 49) y Orosio (VI, 21,5) podría coincidir con la toma del Bernorio. No obstante, según Peralta estas operaciones se desarrollarían en las campañas que dirigió C. Antistio Veto legatus de la Tarraconense, que tomó el mando de las operaciones en el área cántabra tras la enfermedad de Augusto ya en una fase posterior de la guerra (Peralta, 2003, 264-265 y 315-319; Peralta, 2004b, 93-94).

\section{Bergida, BelgiCA, VelLiCA, Attica}

La denominación más antigua conocida documentalmente sobre Monte Bernorio procede de época medieval. En el folio 27 del Becerro de Santa María la Real, se le denomina Brinorulo, término cuyo final recuerda ariuulo 'arroyo'. Aunque conocemos esta denominación de época medieval, desconocemos el nombre o nombres recibidos en época romana. En las cartografías originales que sirvieron de base a los primeros Mapas Cartográficos editados en España sobre la zona ${ }^{1}$, hemos podido constatar que se empleaba indistintamente el término Bernorio y Birnorio. En todo caso, está claramente atestiguado un masculino con una secuencia consonántica $b-r-n-r$ en la composición del nombre que ha pervivido, al menos, desde época medieval.

La denominación Brinorulo parece una forma antigua en diminutivo del actual Bernorio. Podría estar relacionado con el topónimo helvecio Brenodurum, la actual Berna (Suiza), formado por las raíces célticas *brano-/breno-"cuervo"o tal vez *brigno- "colina" (aunque de haberse conservado la raíz *brigno- en latín, al evolucionar al romance debería haber resultado breño-, a no ser que al adaptar el topónimo al latín se hubiera simplificado en Brinodurum) y *duro-"puerta- mercado- foro", muy frecuente en la toponimia, teonimia y etnonimia céltica europea ${ }^{2}$. La evolución fonética de Breno-

1 Los originales han sido consultados en el Instituto Geográfico Nacional y en ellos constan las anotaciones realizadas por los cartógrafos en su trabajo sobre el terreno. Estas se refieren a poblaciones, fuentes, parajes, caminos, etc. con el nombre que tenían a comienzos del siglo XX. Hemos de pensar que dichos nombres están tomados a partir de las informaciones de los habitantes locales.

2 Augustodurum (Bayeux); Autessiodurum (Auxerre); Boiodurum (Innstadt-bei-Passau); Briuodurum (Briare); Durobriua Cantiacorum (Rochester); Durobri- 
durum hasta Bernorio no ofrece ningún problema (metátesis RE a ER; lenición de D intervocálica en -durum, Brenodurum $>$ Brenouro $>$ Bernorio, con la inclusión de una vocal epentética /i/ entre la consonante y vocal finales), excepto por la forma intermedia medieval Brinorulo, que tal vez sea una hipercorrección o un error de transcripción, algo nada infrecuente. También este término lo encontramos en la denominación de la ciudad de Brno (Chequia), territorio de los Boii, lo que refrendaría el carácter céltico de la voz.

Resulta bastante probable que el importante oppidum situado en Monte Bernorio, por su estratégica ubicación y características como uno de los puntos clave en la guerra cantábrica, fuera nombrado en las fuentes grecolatinas. En el yacimiento se han encontrado niveles de destrucción y restos de armamento indígena y romano que indican un final violento a manos de las legiones romanas, con toda probabilidad en las denominadas "Guerras contra Cántabros y Astures” (Torres Martínez, 2007; Torres Martínez et alii, 2011, 132-135, 137-143; Torres Martínez et alii, 2012b, 150-151; Torres Martínez et alii, 2012c; Torres Martínez y Martínez, 2012,3234, 36-40; Torres Martínez et alii ,2013a, 57-63; Torres Martínez et alii, 2013b, 20-22).

Al menos por el momento, no conocemos cual podría ser su denominación prerromana o romana a través de la epigrafía pero, ¿podemos esperar que aparezca el nombre indígena en la epigrafía o en los textos?

Hay que tener en cuenta que la fuente primaria de la mayor parte de los autores antiguos que hablan de este pasaje es Tito Livio, autor enormemente impreciso en cuestiones de onomástica hispánica antigua. En las fuentes clásicas conservadas, para

ua Catuuellorum (Water Newton); Durocatalaunum (Châlons-en-Champagne); Durocobriuis (Dunstable); Durocornouium (Wamborough); Durocoiregum(Domqueur); Durocortorum (Reims); Duroleuum (Davington); Duroliponte (Cambridge); Durolitum(Harold Wood, Romford); Duronum (Warpont, Etroeungt); Durostorum (Silistrie); Durotincum (Villar-d'Arêne; Villejoubert); Durouernum (Canterbury); Durouigutum (Goldmanchester); Epomanduodurum (Mandeure); Ictodurum (Bâtie-Neure); Isarnodurum (Izernore); Lactodurum (Towcester); Octodurum (Martigny); Durotriges, Durocasses (etnónimos); Durotincius (teónimo); Duratios (antropónimo). En España tenemos en territorio ástur Bergidum (actualmente El Bierzo), el populus ibérico de los bergistanos en el Pirineo y el topónimo moderno Valberga en el área vadiniense de la actual provincia de León. lo que supuestamente es un mismo emplazamiento, encontramos cuatro denominaciones: Attica, Belgica, Bergiday Vellica. Attica se tiene por un nombre totalmente corrompido y no se toma en cuenta. Sin embargo hemos de tener en cuenta que es la denominación dada por el único autor de origen hispano, Orosio, y tanto la raíz *att- como el segmento final -ic- están bien testimoniados en la documentación hispano-céltica. Belgica (en los códices $<<\mathrm{C} \gg>$ de los Epitomae de Floro) parece igualmente una corrupción de Bergida, que es el nombre que se tiene por una lectura más fiable. Finalmente Vellica se acepta también como un posible nombre del emplazamiento, ya que por la epigrafía conocemos una gens llamada Vellicum ${ }^{3}$ representada en el cercano yacimiento de Monte Cildá. Además, Vellica ofrece una mejor base para entender las denominaciones Attica y Bergida/Belgica por corrupción gráfica o fonética de la primera que viceversa $^{4}$. Ambos topónimos, Bergida y Vellica ofrecen además una buena proyección etimológica en el ámbito céltico contando asimismo con una amplia representación en topónimos, teónimos y etnónimos en el resto del mundo céltico. Bergida deriva del céltico *bergo-/bergona-/bergusia: "altura-monte-montaña" 5 . Es evidente que el monte Bernorio destaca sobre el territorio circundante precisamente por ser una gran elevación rodeada de llanuras y aislada del resto de la cordillera, por lo cual un nombre como Bergida "la montaña" sería muy apropiado. De hecho, en el norte de Castilla y León y en la Cantabria actual perviven también en la actualidad abundantes topónimos similares como Monte, Cueto, Mata, Peña, etc. El nombre Vellica también podría ser céltico, derivado quizá de la raíz

3(C.I.L., II, 6297) D(is) M(anibus)/Val(erio) Quadrato / Boddi filio vel/lic(um) an(norum) XL Mali/a uxsor Magilo/nis f(ilia) monime/ntu(m) posuit/ Fulvio Pio et Pontio Pontiano ob memoriam. "A los dioses Manes. A Valerio Cuadrato, hijo de Boddo, de los Vellicos, de 40 años. Su esposa Malia, hija de Magilón, puso el monumento siendo cónsules Fulvio Pio y PontioPontiano. En memoria”.

4 Debemos mencionar la existencia de una Bélgidal Belgeda en la Celtiberia que es citada por Apiano (Iber. 100) con motivo de la sublevación de los celtíberos del 93 a.C. y por Orosio $(\mathrm{V}, 23,11)$ para el 75-76 a.C. en relación con la toma de este núcleo por Pompeyo (Burillo, 2007: 94, 106, 198-199, 233, 249, 314-315, 386, 394 y 274: Cuadro 3).

5 Bergonna (Bergonne, Pas-de-Calais); Bergintrum (Bourg-Saint-Maurice); Bergusia (teónimo Alise-SainteReine); Bergimus (teónimo, Brescia); Bergonia (teónimo, Viens); Matuberginnis (teónimo, Rivières); Bergomum (Bérgamo). 
*velio- /vello-: “modesto-honesto-mejor”, también con una abundante presencia en la onomástica toponimia célticas. *Velio- aparece además como geminado en antropónimos, etnónimos y topónimos, y se interpreta como la misma raíz. En este sentido, resulta plausible que Vellica fuera un topónimo posterior a la guerra cantábrica, que habría sustituido al topónimo original Bergida, quizás por la influencia local de la etnia de los Vellici. Este topónimo aparece en la inscripción de Monte Cildá, donde Vellicum aparece como genitivo de plural en la forma indígena en lugar de la latina -orum, por tanto su nominativo plural debería ser Vellici en latín y Vellicos en castellano.

En resumidas cuentas, podemos concluir que las fuentes clásicas emplean distintas denominaciones para un mismo emplazamiento: Attica (en la Historia adversos paganos de Orosio), Belgica (en los códices llamados $\langle<\mathrm{C}\rangle\rangle$, de los Epitomae de Floro, producto de la fusión del $\ll<\mathrm{N} \gg$ o Palatinus Latinus y el $\ll$ L $\gg$ o LeidensisVossianus), Bergida (según el considerado mejor códice, también de Floro, el $<<\mathrm{B}>>$ o Bambergensis) y Vellica (citada por Ptolomeo en Geographica II, 6, 50 y tal vez relacionada con la Villegia del Itinerario de Barro, que no aparece en las fuentes referentes a la conquista).

4. OPPIDA CÉlTICOS Y DENOMINACIONES DE LOS NÚCLEOS Y LAS ETNIAS QUE HABITAN SU TERRITORIO

Como ocurre con el caso de Monte Bernorio, en el área del cantábrico en la mayoría de los casos todavía no se puede establecer una relación segura entre las denominaciones de los oppida y de los populi y nationesque los autores grecolatinos nos han dejado. La documentación arqueológica de los núcleos fortificados y su identificación con oppida nombrados en los textos grecolatinos resulta relativamente compleja. No obstante, existen ejemplos a este respecto, como ocurre con el castro de la Campa Torres (Gijón, Asturias) que fue identificado por sus excavadores como el oppidum de Noega que menciona Plinio en su Historia Natural (IV, 34,111) (Maya, 2000; Maya y Cuesta, 2001, 261-268). Del mismo modo, el Castro de Peña Sámano (Castro Urdiales, Cantabria) ha sido identificado por sus investigadores como "Oppidum Samanorum" (Bohigas et alii, 1999; 2004, Bohigas y Unzueta, 2011; Martínez Velasco, 2010, 569-572).

Tanto las denominaciones de los núcleos, como las de las etnias, provienen abrumadoramente de los autores grecolatinos o de la epigrafía. De este modo, las nóminas más extensas de este tipo son básicamente proporcionadas por autores como Estrabón en su Geografía, Plinio en su Historia Natural y Ptolomeo en su Geografía. A través de estos autores podemos conocer los nombres de una gran cantidad de oppida y de los populi que los habitaban. Parece un recurso habitual entre los autores grecolatinos establecer una denominación similar o equivalente entre la otorgada a un populus (etnia) y la de su núcleo (o viceversa). Éste es el caso del oppidum de Lancia (que se cree ubicado en Arrabalde, Zamora) que sería el núcleo principal de los Lancienses. Similar es el caso del oppidum Koncána de Ptolomeo (Geogr. II, 6, 50), que sería el núcleo principal de los Konkanoi y Orgenomeskon será la "capital" de los Orgenomescos (Caro Baroja 1970, 47-48; 50; Beltrán, 1988, 230-232; Rabanal, 1991, 61-71; Santos, 1992, 427-430; 2004, 2006, 136-142; García Echegaray, 1997, 48-80; Salinas, 1998a, 165-167; Sayas 1999, 190-194; García Quintela, 2002, 74-75). Entre los ástures, en el caso de los Brigaecini, su núcleo se denomina Brigai-

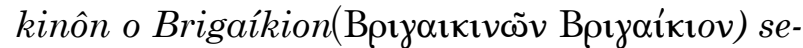
gún Ptolomeo (Geogr. 2,6,29). Nótese que el topónimo ptolemaico estaría directa o indirectamente corroborado por otras fuentes: Brigcecini (Flor. epit. 2,33,1); Briceco y Brigeco (It. Ant. 439.8 y 440.1 respectivamente); Brigecio (It. Ast. 2.3); Brigicon (It. Rau. 319.1); Brigeacis (C.I.L. 2,63381); Brigiaecino (C.I.L: 2,6094) o Aiiobrigiaecinos (bis) en el edicto del Bierzo (Balboa, 1999).

Sin embargo, también existen escenarios diferentes, por ejemplo el caso de los Berones. Si bien el núcleo principal de esta etnia era Ouaria o Uarakos (Estrabón, Geogr. III, 4, 12) -que se identifica actualmente con el yacimiento de La Custodia (Viana, Navarra) y que luego se denominará $V a$ reia o Varia -, sabemos que también tenían otros centros secundarios que actuaban como capitales de subetnias, como es el caso de Libia, Vareia y Tritium (Ptolomeo II, 6, 52; 54 y 64), varios de ellos con ceca y emisiones propias de moneda (Burillo, 2007, 204, 224-226, 228, 273; Labeaga, 2000, 173-181).También encontramos territorios en los que aparentemente no aparece mencionado núcleo principal u oppidum. En algunos casos es probable que los oppida tuvieran nombres que a los autores grecolatinos les resultaran desconocidos o bien que fueron obviados, pero en otros casos es probable que la organización política y territorial fuera diferente, como veremos más adelante. Finalmente, no 


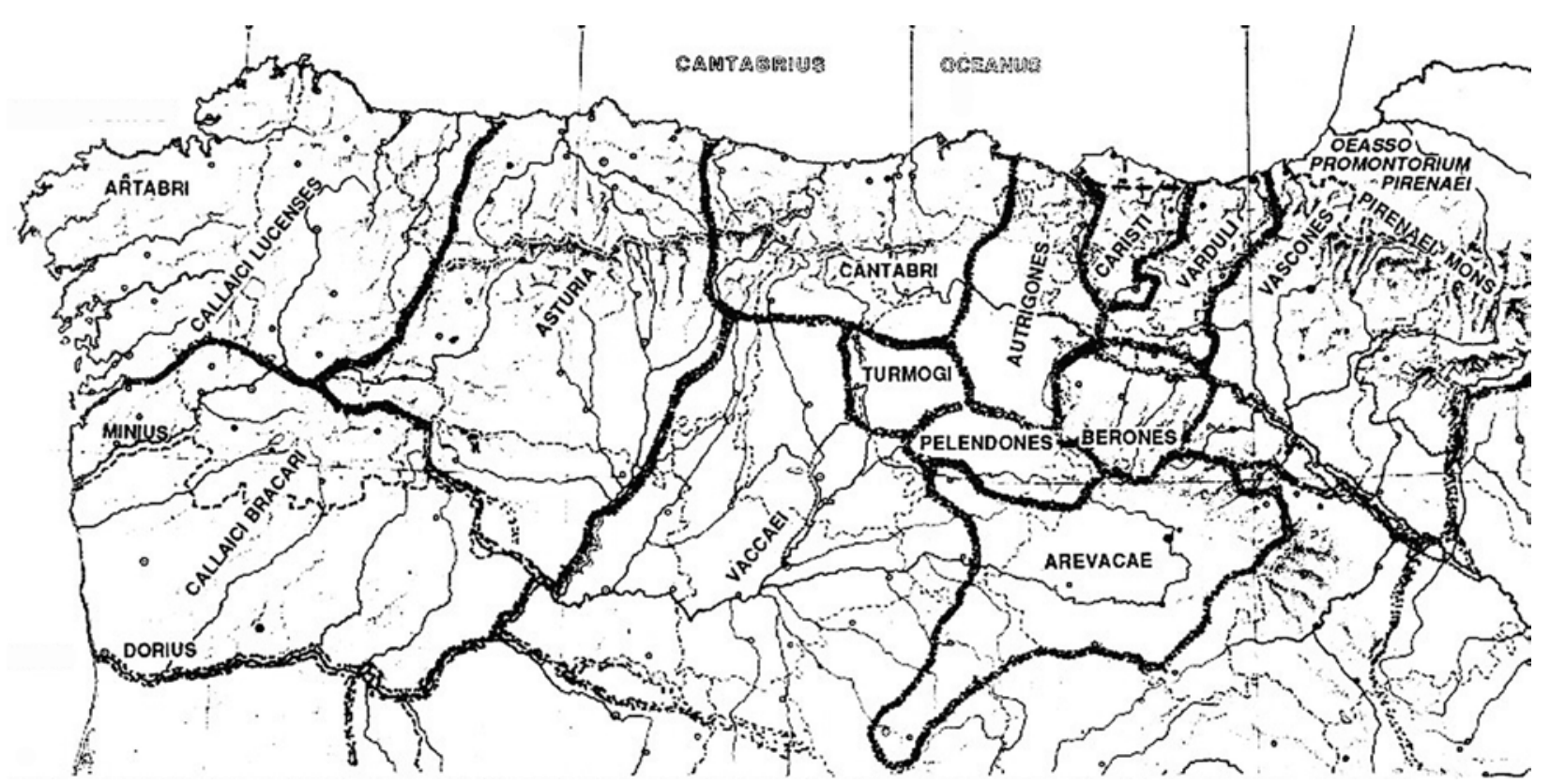

podemos olvidar que hay varios casos conocidos de núcleos con un mismo nombre. En la Beturia céltica y Lusitania es evidente que existen distintas poblaciones con un mismo nombre tal y como indica Plinio (Nat. Hist. IV, 118), entre ellos Mirobriga, Arcobriga, Nertóbriga o Arandis (Berrocal Rangel,1992, 40-41; García Alonso, 2003, 95-96, 101102, 439-440, 444-445).

Otra cuestión a tener en cuenta es que algunos oppida han recibido varias denominaciones o son conocidos por más de un nombre. Los oppida, como otros tipos de poblaciones, pueden recibir nombres diferentes de sus propios habitantes y de sus vecinos por distintas motivos. Además debemos considerar las diferencias diacrónicas o los cambios producidos en la denominaciones a través del tiempo, como es el caso de Saguntum-Ars[e] o Tarraco-Cesse. Habría que valorar qué cambios importantes en la estructura política y social del grupo, como una conquista, una anexión o un proceso de sinecismo, o bien una refundación tras una destrucción o por un motivo de tipo religioso, llevarían parejo un cambio de nombre. Además, pueden tener otros tipos de apelativos o epítetos que sirvan para denominarlas, como sobrenombres, que pueden ser tan conocidos y usados como el propio nombre.

5. CUESTIONES RELACIONADAS CON LAS ETNIAS Y LOS OPPIDA CÉLTICOS DEL NORTE DE LA PENINSULA IBÉRICA

A lo largo de este trabajo empleamos una termi- nología latina para referirnos a realidades propias de la cultura céltica. Desde el presente percibimos una vaguedad, ambigüedad e imprecisión aparente en la terminología con que los autores grecolatinos definen las estructuras sociales de los pueblos prerromanos. Esto supone una dificultad para comprender y definir de modo seguro y preciso las distintas instituciones sociales de estos pueblos. No obstante, estudios recientes se alejan de las posturas netamente escépticas y reivindican el valor de los testimonios grecolatinos y su terminología para el conocimiento de las sociedades protohistóricas (Kraus, 2009; Woolf, 2009; 2011).

Resulta difícil admitir que los romanos no tuvieran un conocimiento suficiente sobre los pueblos que conquistaron. Costosas campañas de conquista militar, como las que se realizaron en el cantábrico, estaban minuciosamente preparadas y desarrolladas, contándose con numerosas informaciones acerca de los territorios que se pretendía conquistar y de los pueblos a los que se quería someter. Averiguar qué grupos resultaban más hostiles, neutrales o más amigables era una cuestión esencial. Por otro lado, se sabía cuáles eran las vías de comunicación que se debían seguir, cuáles eran los núcleos que las defendían, cómo se llamaban y quienes las habitaban, así como otra información de tipo militar sobre el tipo de asentamiento, defensas, entorno donde establecer campamentos de asedio, etc. Por tanto es evidente que los mandos de las legiones re- 
clutaban espías, intérpretes y guías para averiguar todos estos datos. Ese tipo de informaciones, debían estar en manos de los mandos de las legiones o de los funcionarios imperiales, tal vez como parte del patrimonio personal o familiar y/o de las unidades. Aunque actualmente la información se haya perdido, sabemos que existía. Conocemos que estas actividades se practicaban ya en época tardo-republicana y se mantuvieron hasta época tardo-imperial (Ezov,1993; Austin y Rankov, 1995; Guzmán, 2004, 33-41; Cadiou, 2006). No deberíamos juzgar el conocimiento existente en Roma sobre estas cuestiones únicamente a partir del material que se ha conservado, pues es mucho más lo que se ha perdido. Desde esta perspectiva el presunto desconocimiento de los territorios conquistados aparece como un producto actual fruto de lo que el tiempo nos ha arrebatado.

Las fuentes clásicas, a partir de los datos de autores como Pomponio Mela o geógrafos como Estrabón y especialmente Plinio "el Viejo" y Ptolomeo nos dan una serie de datos sobre sus límites políticos y geográficos, la denominación y en algunos casos la ubicación aproximada de sus núcleos más destacados (Schulten, 1987, 77-78, 183-198; Un- zueta, 1994, 102-104; García Alonso, 2003, 12-13, 26-28; Burillo, 2007, 42-46, 50-56; Beltrán, 2012; Cruz Andreotti, 2007; Traina, 2007). La conquista militar del centro y occidente del cantábrico en época de Augusto fue muy costosa, y con un buen número de sublevaciones que prolongan el conflicto durante décadas. Por estos motivos, resulta difícil creer Roma no haya realizado ningún reajuste territorial ni ninguna represalia que suponga un recorte o una variación de la integridad territorial de aquellos pueblos, especialmente los más pertinaces en la lucha. Y que no hubiera recompensado a otros que mantuvieron actitudes más pacíficas o de abierta colaboración (Fernández Posse, 2002, 84; Fernández Posse y Sánchez Palencia, 1998).

En todo caso, los datos más exactos conocidos sobre la distribución territorial del norte de la Península Ibérica provienen del siglo II d. C., y en este momento ha pasado ya más de un siglo desde que se terminó la conquista de la franja cantábrica de la Península Ibérica. Se han producido algunos cambios importantes en la situación política de esta región, aunque tal vez no tantos como cabría esperar. Parece evidente que una vez terminada la conquista, la cuestión étnica tiene más un valor ad-

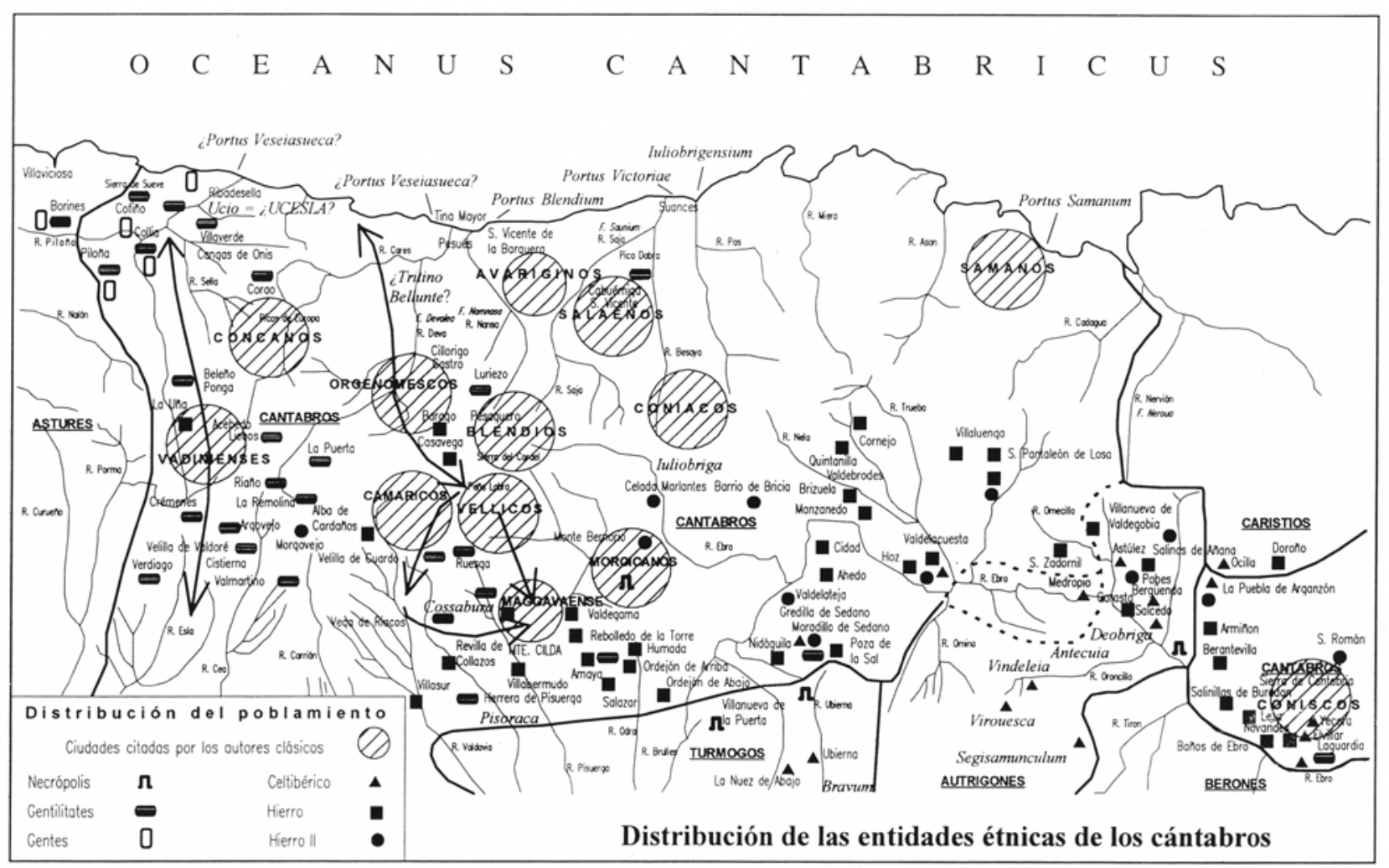


ministrativo para Roma, que sirve para facilitar la gestión de los territorios (Beltrán, 2012, 492-496).

F. Burillo (2007, 62-64) llama la atención sobre un trabajo de J. M. Roldán en el que se recoge la diferencia existente en el modo de reclutamiento entre las unidades legionarias y las de auxiliares en la Península Ibérica (Roldán, 1974, 270-271). Las legionarias se reclutan entre romanos hispanos encuadrados por unidades administrativas romanas, provincias y conventos, en las zonas más romanizadas que son las provincias de la Bética y la Tarraconense. Pero los auxilia se reclutan según su origen étnico (por etnias y subetnias) en la provincias de la Lusitania y la Tarraconense. Es este el caso de galaicos, astures, cántabros, caristios, várdulos, vascones, arévacos y celtíberos. Es evidente que existe una diferencia clara entre la organización territorial del reclutamiento entre territorios romanizados (legiones) y otros que no lo están tanto (auxilia). En los últimos, es indudable que Roma aceptó, aun con cambios y reajustes, una gran parte de la organización política y territorial anterior a la conquista. Esta estructura político-territorial prerromana sirve para el control de estos territorios, pero es diferente de la que se puede aplicar a los territorios plenamente romanizados del levante y sur peninsular. Esto permitió la pervivencia de una parte importante de la organización territorial del norte de la Península Ibérica indígena que quedó, al menos aparentemente, "fosilizada" durante un largo periodo de tiempo. Dicha organización estaba basada en los territorios étnicos y los oppida.

Por otro lado está el problema esencial de la identificación de las correspondencias entre los lugares mencionados en las fuentes y aquellos yacimientos arqueológicos localizados hasta el momento. La inmensa mayoría de las atribuciones son estimaciones sin argumentos lo suficientemente sólidos. En muy pocas ocasiones podemos asegurar realmente que determinado yacimiento arqueológico se corresponde con determinado núcleo que aparece en los textos grecolatinos. Esto es así por varios motivos. Primero, porque los yacimientos conocidos en la abrumadora mayoría de los casos no han sido suficientemente investigados. Segundo, porque existen indicios suficientes para sostener que futuras campañas sistemáticas de prospección aumentarían considerablemente el número de yacimientos existentes hasta el momento, con lo que el panorama cambiaría y habría que replantear aquellas adjudicaciones no confirmadas arqueológicamente, que son la inmensa mayoría (Valle y Serna, 2003, 355-356; Solana Sainz, 2003, 60-70). Así pues, en la actualidad estamos trabajando con datos que debemos considerar meramente circunstanciales y con un valor solamente temporal limitado tan solo a la capacidad investigadora que podamos desarrollar en las próximas décadas (Llanos, 1992, 431; Burillo, 2007, 257-259).

Otra cuestión importante es la de las distintas denominaciones que reciben los oppida, los territorios y etnias que los habitan. Estas sufren cambios en los textos de los autores grecolatinos a lo largo de los siglos según mejora progresivamente el conocimiento de los territorios y los pueblos. También debemos considerar, como hemos adelantado anteriormente, que determinados núcleos pueden sufrir refundaciones por diversos motivos: tras una destrucción, un fenómeno de sinecismo o una cuestión de orden religioso. Para los autores grecolatinos territorio geográfico, político y populus reciben denominaciones relacionadas y equivalentes por lo que cabe pensar que el populus denomina también al territorio que ocupa, que es el ámbito políticoadministrativo. Como hemos visto anteriormente, los oppida y sus territorios reciben con mucha frecuencia la misma denominación que el populus que sitúa en estos su "capitalidad". O viceversa, el populus se denomina a partir del nombre del oppidum donde se establece su capitalidad. Al menos esto es lo que se puede inferir de la revisión de los textos de autores como Plinio o Ptolomeo. En todo caso, parece claro que dichas denominaciones no son geográficas, sino étnicas y que los territorios reciben el nombre de las etnias que los habitan (Caro Baroja, 1970, 38-45; Beltrán, 1988, 204-207; Salinas, 1998, 165-167; Peralta, 2003, 119-128; Torres Martínez, 2011a, 366-367).

A partir del siglo III a.C., las poblaciones más grandes, mejor defendidas y con mayor proyección estratégico-territorial se convierten en los centros que vertebran la organización política y militar de los territorios: los oppida. Estos grandes núcleos, como ocurre en otras zonas de la Península Ibérica y de Europa, se convirtieron en elementos jerarquizadores del territorio donde se concentraban funciones de tipo político-administrativas y también religiosas (Collis, 1984; Wells, 1988, 13-22, 30-31, 129-164; Almagro Gorbea, 1994, 1996, 1999, 36-37, 42, 39-42, 2002, 54-57; Burillo, 2011; Fernández Götz, 2013; 2014b). Por debajo de ellos estaban los castros de dimensiones más reducidas y finalmente 
las aldeas y granjas. Esta jerarquización viene determinada esencialmente por cambios de tipo socioeconómico y por la existencia de una situación bélica latente, lo que lleva a unas crecientes necesidades de defensa colectiva. En este sentido, es importante comprender que los oppida no sirven solo para defender a una parte de la población o a una elite social que habita en su interior sino a todo el conjunto del territorio, con el esfuerzo y el concurso militar de los habitantes de un amplio entorno (Burillo, 2007, 252-257; Torres Martínez, 2011a, 274-280, 372-374).

La estructura político-territorial de los pueblos del norte de la Península Ibérica en la Edad del Hierro fue ya definida por J. Caro Baroja en un esquema que sigue siendo vigente (Caro Baroja, 1970, 30-31; 1973, 68), y que han seguido también otros autores (Santos, 1998, 300; 2006, 263-271; Salinas, 1998, 165-167). Se pueden distinguir tres niveles principales de organización política y social:

- Una gran unidad étnica: Astures, Cantabri.

- Una subdivisión de esta, subetnia o populus:

Zoelae, Orgenomesci.
- Una división de la anterior que se correspondería a una estructura de tipo supra-familiar o vecinal (local): Desonci, Pembeli.

A esta división podemos añadir otra denominación, la correspondiente a una identidad de tipo transversal que podríamos denominar como "macroétnica”. En el territorio que nos ocupa, Estrabón (III, 3,7$)$ narra como todos los habitantes del área cantábrica tienen un modo de vida similar, y que por ello denomina como "montañeses" a "los que jalonan el flanco norte de Iberia: calaicos, astures y cántabros hasta llegar a los vascones y el Pirene, pues el modo de vida de todos ellos es semejante". En su conjunto se trata de cuatro niveles de identidad étnica y tres niveles conocidos de organización política, social y territorial (Torres Martínez, 2011a; véase también Fernández Götz, 2014a para el ámbito de la Galia).

Por otro lado, es importante señalar que las condiciones geográfico-ambientales del espacio físico septentrional de la Península Ibérica condicionan un tipo de ocupación del territorio que no permite en todas las áreas el surgimiento de la sociedad de

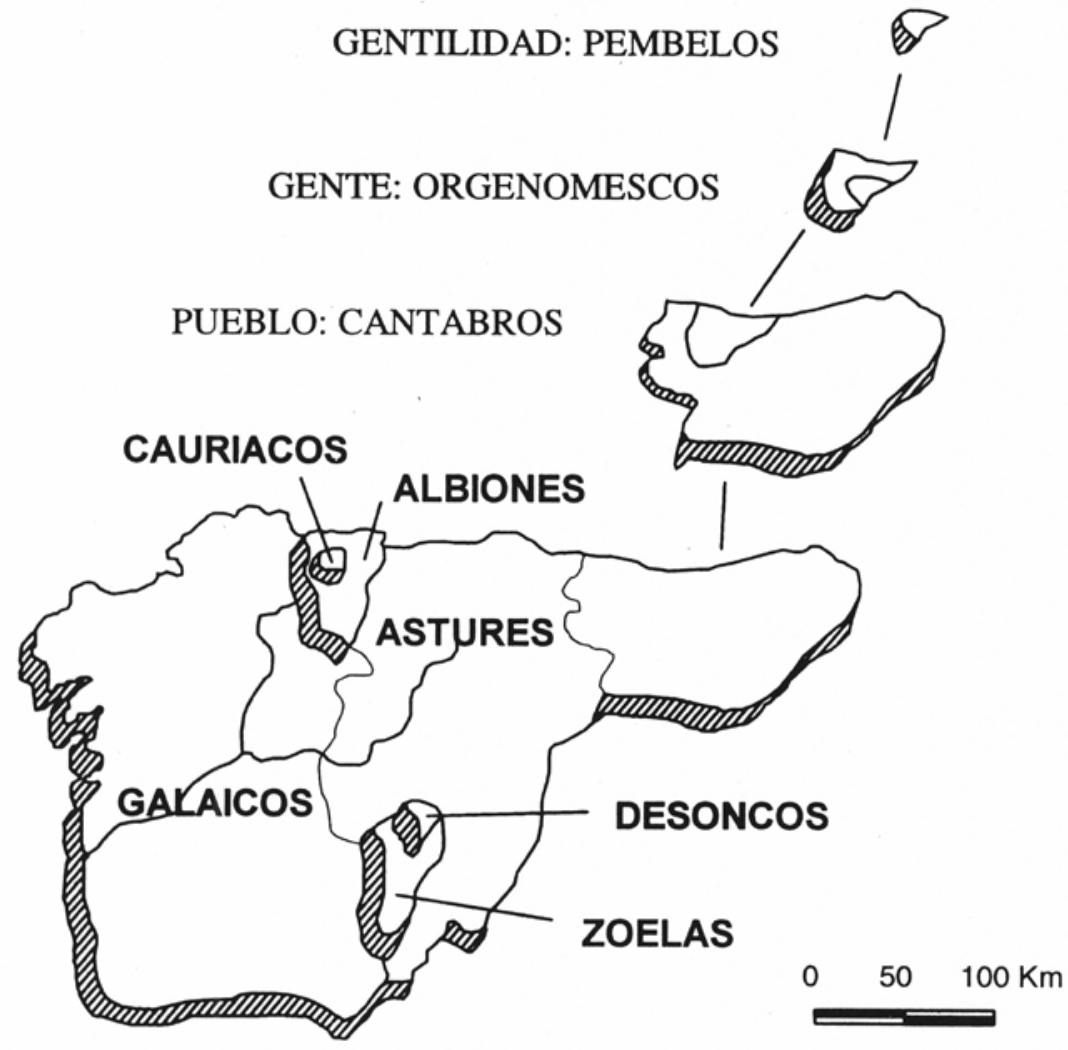


los oppida. Este caso se da en una gran parte de las zonas más occidentales del Cantábrico y es lo que M. Almagro-Gorbea denomina esta área como "Zona III" dentro de su modelo de urbanismo de la "Hispania húmeda" (Almagro Gorbea, 2002, 58). Esto no implica necesariamente un menor nivel de desarrollo cultural y socio-político, sino tan solo un modelo diferente, adaptado a las características de los distintos territorios, sobre todo cuando se trata de paisajes con una geografía abrupta (Pereira, 1982, 1983; Santos, 1985; González Rodríguez, 1986, 81-82, 113; García, Quintela y Santos, 2008, 52-59; Armendáriz, 2008, 239-247, 313-314, 2009, 319-327).

\section{CONCLUSIONES}

Como hemos visto, la cuestión de las denominaciones que reciben en los textos grecolatinos los distintos oppida está en relación con los distintos grupos étnicos que habitaban los diferentes territorios. También hemos podido comprobar lo compleja que resulta su estructura de identidad étnica, con distintos niveles que interactúan dentro de un sistema de identidades integradas (Fernández Götz, 2014a). Incluso es posible encontrar casos de identidades que hemos denominado "trasversales", como la de los montañeses. Posiblemente, más que una identidad étnica asumida por los que así son denominados, sea este tipo de identificación el resultado de una visión "exógena” de un colectivo humano. Esta visión identifica un ente que es diverso, pero que se percibe como lleno de elementos culturales comunes y que habita dentro de un territorio que, desde el punto de vista geográfico y ambiental, es coherente. En todo caso, el comportamiento de los pueblos del Cantábrico Central en las guerras cántabro-astures indica una innegable proximidad cultural y un importante nivel de integración política y militar.

Es evidente que estas identidades implican también una intensa integración en los territorios en los que estos grupos habitaban. Probablemente sea este el resultado de una intensa adaptación (económica en primera instancia, pero también mucho más profundamente cultural) al espacio en el que habitan. Seguramente ésta sea la causa del fenómeno de los casos de pervivencia de estas identidades e instituciones dentro de las estructuras políticoadministrativas del imperio romano.

Para finalizar, es importante subrayar que, como hemos podido constatar, la situación del norte de la
Península Ibérica no es muy distinta de lo que se conoce dentro del ámbito del final de la Edad del Hierro en el centro y occidente de Europa (Fichtl, 2005; Fernández Götz, 2014a).

\section{AgRADECIMIENTOS}

Queremos agradecer las aportaciones y comentarios de X. Ballester al texto de este artículo.

\section{BibLIOGRAFÍA}

\section{Almagro Gorbea, M.}

(1994), "Urbanismo de la Hispania “céltica”, Castros y oppida del centro y occidente de la Península Ibérica”, Castros y oppida en Extremadura (M. Almagro-Gorbea y A. M. Martín, Eds.), Complutum, Extra 4, 13-75.

(1996), "Los castros de la Meseta”. Gallaecia, 1415, 261-308.

(1999), "Estructura socio-ideológica de los oppida celtibéricos", Pueblos, Lenguas y Escrituras en la Hispania Prerromana (F. Villar y F. Beltrán, Eds.), Actas del VII Coloquio sobre Lenguas y Culturas Paleohispánicas, Institución Fernando el Católico y Ediciones Universidad de Salamanca, Salamanca, 35-55.

(2002), "Urbanismo y sociedad en la Hispania Húmeda”, Los poblados fortificados del noroeste de la Península Ibérica: Formación y desarrollo de la Cultura Castreña (M. A. de Blas Cortina y A. Villa Valdés, Eds.), Navia, 47-79.

Almagro Gorbea, M. y Dávila, A. F. (1995), "El área superficial de los oppida en la Hispania Céltica”, Complutum, 6, 209-233.

Armendariz, J.

(2008), De Aldeas a Ciudades. El poblamiento durante el primer milenio a. C. en Navarra, Trabajos de Arqueología Navarra, Monografías Arqueológicas 2, Institución Príncipe de Viana, Pamplona.

(2009), "La ordenación del territorio vascón en la Edad del Hierro", Los vascones de las fuentes antiguas: en torno a una etnia de la Antigüedad peninsular (J. Andreu, Coord.), Barcelona, 303-338.

Assas, M. (1872), Crónica de la provincia de Santander, Ed. Rubio y Compañía, Madrid.

Austin, N. J. E., y Rankov, N. B. (1995), Exploratio. Political and Military intelligence in the Roman World from the Second Punic War to the Battle of Adrianople, New York.

Balboa, J. A. (1999),"Un edicto del emperador Au- 
gusto hallado en el Bierzo", Estudios Bercianos, Revista del instituto de estudios Bercianos, 25, 45-53.

Barril, M.

(1995a), "El Castro de Los Barahones (Valdegama, Palencia): Un Poblado en el Alto Valle del Pisuerga”, III Simposio Sobre Los Celtíberos. Poblamiento Celtibérico, Institución Fernando el Católico (CSIC) y Diputación de Zaragoza, 399-408.

(1995b), "Comentarios sobre el fondo de cabaña de Monte Bernorio", Actas del III Congreso de Historia de Palencia (M. V. Calleja, Coord.), Diputación de Palencia, 153-173.

(1999), "Dos yacimientos de la Edad del Hierro, Castro de Los Barahones y Bernorio", Regio Cantabrorum (J. Iglesias y J. A. Muñiz, Eds.), Santander, 43-52.

Beltrán, F.

(1988), "Un espejismo historiográfico. Las "organizaciones gentilicias” Hispanas”, Actas del Primer Congreso Peninsular de Historia Antigua, Vol.II (G. Perira Menaut, Dir.), Universidad de Santiago de Compostela, 197-237.

(2012), "Plinio versus Ptolomeo. Geografía y etnicidad en la Hispania del principado", Romanización, Fronteras y Étnias en la Roma Antigua: El caso Hispano (J. Santos Yangüas y G. Cruz Andreotti, Eds.), Revisiones de Historia Antigua VII, Universidad del País Vasco, Vitoria, 477-498.

Berrocal Rangel, L. (1992), Los pueblos célticos del suroeste de la Península Ibérica, Complutum Extra, 2, Editorial Complutense, Madrid.

Blázquez, A. (1920), "Cuatro téseras militares", Boletín de la Real Academia de la Historia, LXXVII, 99-107.

Bohigas, R., Unzueta, M., Molinero, J. T., y Fernández, F. (1999), "El castro de Peña Sámano: Oppidum (S)amanorum", Regio Cantabrorum,Santander (J. Iglesias y J. A. Muñiz, Eds.), Caja Cantabria, 79-89.

Bohigas Roldán, R. y Unzueta Portilla, M. (2011), "Las investigaciones Arqueológicas en el Oppidum de la Peña de Sámano (2000-2005)", Castillos de España, 161-163, 15-22.

Burillo, F.

(2007), Los celtíberos. Etnias y estados (Nueva edición corregida y aumentada), Crítica Grijalbo Mondadori, Barcelona.

(2011), “Oppida y "ciudades estado" celtibéricos”,
Aldeas y ciudades en el Primer milenio a.C. La Meseta norte y los orígenes del urbanismo (J. Álvarez Sanchís, A. Jimeno Martínez, y G. Ruiz Zapatero, Eds.), Complutum, 22/2, 277295.

Cabal, C. (1953), Las Asturias que venció Roma, Gráficas Summa, CSIC, Oviedo.

Cabré, J. (1931): “Tipología del puñal en la Cultura de "Las Cogotas", Archivo Español de Arte y Arqueología, VII, 221-241.

Cabré Aguiló, J. y Cabré Herreros, M. E. (1933), "Datos para la cronología del puñal de la cultura cogotas”, Archivo Español de Arte y Arqueologia, IX, 37-45.

Cadiou, F. (2006), "Renseignement, espionnage et circulation des armées romaines: vers une Géographie militaire de la Péninsule Ibérique à l'Époque de la conquête», La Invención de una Geografía de la Península Ibérica. I La Época Republicana (G. Cruz Andreotti, P. Le Roux, y P. Moret, Eds.), Diputación de Málaga y Casa de Velázquez, Málaga, 135-152.

Canal, J.M.(1981), El concejo de Burón: su gloriosa Historia, Editorial León Celarayn, España.

Caro Baroja, J.

(1970): "Organización social de los pueblos del norte de la Península Ibérica en la Antigüedad”, Legio VII Gemina, Diputación Provincial de León, 11-62.

(1973), Los pueblos del Norte de la Península Ibérica, Análisis histórico-cultural, Editorial Txertoa, San Sebastian.

Collis, J.

(1984), Oppida. Earliest towns north of the Alps, Departament of Prehistory and Archaeology, University of Sheffield Eds., Sheffield.

Cruz Andreotti, G. (2007), "Estrabón y la tradición geográfica”, Geografía de Iberia. Estrabón, Traducción de F. J. Gómez Espelosín, Biblioteca Temática, vol. 8288, Clásicos de Grecia y Roma, Alianza Editorial, Madrid, 44-66.

Ezov, A. (1993), "The "missing dimension" of C. Julius Caesar”, Historia, XLV, 1, 64-94.

Fernández Götz, M. A.

(2011), "Niveles sociopolíticos y órganos de gobierno en la Galia de finales de la Protohistoria”, Habis, 42, 7-26.

(2013), "Una nueva mirada sobre los oppida de la Europa Templada”, Complutum, 24/1, 131-150. (2014a), De la familia a la etnia: Protohistoria de la Galia Oriental, Bibliotheca Archaeolo- 
gica Hispana, 41, Real Academia de la Historia, Madrid.

(2014b), "Reassessing the Oppida: The Role of Power and Religion", Oxford Journal of Archaeology, 33/4, 379-394.

Fernández Guerra, A. (1872), El libro de Santoña, Imprenta de Manuel Tello, Madrid.

Fernández Ochoa, C., Morillo, A. y Gil, F. (2012), "El "Itinerario de Barro", cuestiones de autenticidad y lectura”, Zephyrus, 70, 151-179.

Fernández Posse, M. D. (2002), "Tiempos y espacios en la cultura castreña”, Los poblados fortificados del noroeste de la Península Ibérica: Formación y desarrollo de la Cultura Castreña (M. A. Blas Cortina y A. Villa Valdés, Eds.), Homenaje al Prof. Dr. José Manuel González y Fernández-Valles, Parque Histórico del Navia, Ayuntamiento del Navia, Navia, 81-95.

Fernández Posse, M. D. y Sánchez Palencia, F. J. (1988), La Corona y el Castro de Corporales II: Campaña de 1983 y prospecciones en la Valdeira y La Cabrera (León), Excavaciones Arqueológicas en España, 152, 55-64.

Fichtl, S.

(2005), La Ville Celtique. Les oppida de 150 av. J.-C.à 15 ap. J.-C. (Deuxième édition revue et augmentée), Éditons Errance, Paris.

(2012), Les premières villes de Gaule. Les temps des oppida celtiques, Collection Archéologie Vivante, Editions Archéologie Nouvelle.

Florez, H. (1768), La Cantabria. Disertación sobre el sitio y extensión que tuvo en tiempo de los romanos la región de los cántabros, con noticias de las regiones confinantes y de varias poblaciones antiguas, Ed. Antonio Marín, Madrid.

García Alonso, J. L. (2003), La Península Ibérica en la Geografía de Claudio Ptolomeo, Anejos de Veleia, Serie Minor 19, Universidad del País Vasco, Vitoria.

García Quintela, M. V. (2002), "La organización socio-política de los populi del noroeste de la Península Ibérica. Un estudio de antropología política histórica comparada", Traballos de Arqueoloxia e Patrimonio, 28, 16-122.

García Quintela, M. V. y Santos Estévez, M. (2008), Santuarios de la Galicia Céltica. Arqueología del Paisaje y religiones comparadas en la Edad del Hierro, con la Colaboración de R. Brañas Abad, Lecturas Serie Historia Antigua, Abada Editores, Madrid.
García Bellido (1975), "El Llamado "Itinerario de Barro", Boletín de la Real Academia de la Historia, 172.3, 547-563.

Gil Zubillaga, E.

(1993), "El poblado de Atxa (Vitoria), un ejemplo de asentamiento de la II Edad del Hierro con aculturación celtibérica en el valle del Zadorra", Bajo Aragón Prehistoria, Vols. IX-X, Segundos Encuentros de Prehistoria Aragonesa, Fundación Fernando el Católico, Zaragoza, 167-174.

(1995): Atxa: Memorias de las excavaciones arqueológicas 1982-1988, Departamento de Cultura, Diputación Foral de Álava, Vitoria.

Gil Zubillaga, E. y Filloy Nieva, I (1986), “El poblamiento durante la Edad del hierro en el Treviño occidental”, Estudios de Arqueología Alavesa, 3, 149-217.

González Echegaray, J.

(1977), Cantabria a través de su historia, Institución Cultural de Cantabria, Diputación Provincial, Santander.

(1997), Los Cántabros, Ed. Librería Estudio, Santander.

(1999b), "Las guerras cántabras en las fuentes”, Las Guerras Cántabras, Santander, 145-169.

González Rodríguez, M. C. (1986), Las unidades organizativas indígenas del área indoeuropea de Hispania, Veleia Anejo 2, Vitoria.

Guzmán, F.J. (2004), "Intérpretes militares y movimientos de información táctica en el frente oriental según Amiano Marcelino", Aqvila Legionis, 5, 29-43.

Kraus, C. S. (2009), "Bellum Gallicum”. A Companion to Julius Caesar (M. Griffin, Ed.), Blackwell, Oxford, 159-174.

Labeaga Mendiola, J. C.

(2000), La Custodia, Viana, Vareia de los Berones, Trabajos de Arqueología Navarra, Monográfico Especial 14, 1999-2000, Pamplona.

Llanos, A. (1992), "Conformación de las etnias prerromanas en Álava, Bizkaia y Guipúzkoa”, Paleoetnología de la Península Ibérica (M. Almagro-Gorbea y G. Ruiz Zapatero, Eds.), Complutum 2-3, Madrid, 431-447.

Martínez Velasco, A. (2010), "Castro de la Peña Samano", Castros y Castra en Cantabria. Fortificaciones desde los orígenes de la Edad del Hierro a las Guerras con Roma. Catálogo, revisión y puesta al día (A. Serna, A. Martínez y V. Fernández, Coords), Santander, 569-572.

Martino, E. (1995), Roma contra Cántabros y As- 
tures. Nueva lectura de las Fuentes, Colección "Breviarios de la Calle del Pez”, Diputación Provincial de León, León.

Maya González, J. L. (2000), “Castros Asturianos: cronología y atribución étnica", I Seminariu d'Estudios Astruianos de la Fundación Belenos. Cuestiones d'Antorpoloxía y Arqueoloxía, Homenaje al Profesor José Luis Maya González, La Puela d'Allande, Payares 2000, Fundación Belenos, Oviedo, 21-39.

Maya González, J. L. y Cuesta Toribio, F. (2001), El Castro de la Campa Torres. Periodo Prerromano, Serie Patrimonio 6, Gijón.

Moro, R (1891), "Exploraciones Arqueológicas. Monte Cildá. Monte Bernorio. Loncejares. Arconada", Boletín de la Real Academia de la Historia, XVIII, 427-440.

Muñiz, J. (1994), "Pueblos y Comunidades Celtas e Ibéricas. Un análisis de los términos literarios", Hispania Antiqua, XVIII, 77-89.

Navarro, R. (1939), Catálogo Monumental de la Provincia de Palencia, Fascículo Tercero, Partidos de Cervera del Río Pisuerga y Saldaña, Comisión Provincial de Monumentos Históricos y Artísticos, Ed. Imprenta Provincial de Palencia, Palencia.

Ortiz de Urbina, E. (2005),“Autrigones Caristios, Várdulos, Berones. Contribuciones Historiográficas (1983-2003) relativas a su evolución en época prerromana y romana", Vasconia, 34, 47-88.

Peralta, E.

(2003), Los Cántabros antes de Roma, 2a Edición Corregida y Ampliada, Bibliotheca Archaeologica Hispana, 5, Madrid.

(2004a), "La conquista romana de Campoo: arqueología de las guerras cántabras”, Cuadernos de Campoo, 36, 28-42.

(2004b), "Cuestiones Histórico-Arqueológicas sobre el Bellum Cantábricum y el desembarco romano en la costa cántabra", Sautuola, X, 85130.

(2006), "La revisión de las Guerras Cántabras: novedades arqueológicas en el norte de Castilla", Arqueología militar romana en Hispania II: producción y abastecimiento en el ámbito militar (A. Morillo, Ed.), Universidad de León, León, 523-547.

Pereira, G.

(1982), "Los castella y las comunidades de Gallaecia”, Zephyrus, XXXIV-XXXV, 249-267.
(1983), "Los castella y las comunidades de Gallaecia”, Actas del II Seminario de Arqueología del Noroeste, Ministerio de Cultura, Dirección General de Bellas Artes y Archivos, Madrid, 167-192.

Rabanal, M. A. (1991), “Astures”, Las Entidades Étnicas de la Meseta Norte de Hispania en Época Prerromana, Anejos de Hispania Antiqua, 61- 71.

Roldán, J. M. (1974), Hispania y el Ejército Romano. Contribución a la Historia Social de la Hispania Antigua, Universidad de Salamanca, Salamanca.

Román, W. (2013), El monte Bernorio en la Guerra Civil: La disputa por un enclave estratégico, Colección de Historia de la Montaña $\mathrm{Pa}-$ lentina, 7, Editorial Aruz, Palencia, 87-130.

Ruiz Alonso, F. (2013), Aguilar, Barruelo y Reinosa en la Guerra Civil. Ofensiva del Frente Norte Palencia-Santander, Editor S.A., Madrid.

Sacristán de Lama, J. D. (2011), "El urbanismo vacceo”, Aldeas y ciudades en el Primer milenio a.C. La Meseta norte y los orígenes del urbanismo (J. Álvarez Sánchís, A. Jimeno Martínez y G. Ruiz Zapatero, Eds.), Complutum, 22/2, 185-222.

Salinas, M. (1998), "La guerra de cántabros y astures, la etnografía y la propaganda de Augusto”, Romanización" y "reconquista" en la Península Ibérica: nuevas perspectivas, Acta Salmanticensia, Estudios Históricos y Geográficos 105, Universidad de Salamanca, Salamanca, 155170.

San Miguel, L. C. (1995), "Civitas y secundarización de la producción iLas dos claves de interpretación del poblamiento vacceo?", III Simposio sobre Los Celtíberos. Poblamiento Celtibérico, 1991, Institución Fernando el Católico (CSIC) y Diputación de Zaragoza, Zaragoza, 373-380.

San Valero, J.

(1944), Excavaciones Arqueológicas en Monte Bernorio (Palencia). Primera Campaña, 1943, Informes y Memorias 5, Madrid.

(1960), Monte Bernorio. Aguilar de Campoo (Palencia). Campaña de Estudio en 1959, Excavaciones Arqueológicas en España, 44, Palencia. Santos, J.

(1985), Comunidades Indígenas y administración romana en el noroeste hispánico, Servi- 
cio Editorial Universidad del País Vasco, Bilbao. Santos, N.

(1992), “Astures y cántabros: Estudio etnogeográfico”, Paleoetnología de la Península Ibérica (M. Almagro-Gorbea y G. Ruiz-Zapatero, Eds.), Madrid, 417-430.

(1998), "Poblamiento antiguo entre los ástures. Los castros", Los Pueblos prerromanos del norte de Hispania: una transición cultural como debate histórico (J. F. Rodríguez Nelia y F. J. Navarro Santana, Eds.),Pamplona, 271-300.

(2004), "Lancia de los Astures: ubicación y significado histórico”, Hispania Antiqua, XXVIII, 71-86.

(2006), Asturias, los astures y la cultura castreña, Oviedo.

Sayas, J. J. (1999), Unidad en la diversidad: la visión de Estrabón de algunos pueblos Penínsulares, Estrabón e Iberia: nuevas perspectivas de Estudio (G. Cruz Andreotti, Coord.), Servicio de Publicaciones de la Universidad de Málaga, Málaga, 153-208.

Schüle, W.

(1969), Die Meseta-Kulturen der IberischenHalbinsel. Mediterrane und Eurasische elemente in Früheisenzeitlichen Kulturen Südwesteuropas, Deutsches Archäologisches Institut Abteilung Madrid, Walter de Gruyter \& Co, Berlin.

Schulten, A. (1987), Hispania Antigua según Pomponio Mela, Plinio el Viejo y Claudio Ptolomeo, Fontes Hispaniae Antiquae, VII (A. Schulten y J. Maluquer de Motes, Dirs.), Trad. V. Bejarano, Instituto de Arqueología y Prehistoria, Barcelona.

Sojo y Lomba, F. de (1947), Cantabria, Madrid.

Solana, J. M. (1993), "Centros urbanos y administración del territorio en la Submeseta septentrional de Hispania (s. I-II d. C.)", Hispania Antiqua, XVII, 159-182.

Syme, R. (1989), La revolución romana, Editorial Taurus, Madrid.

Torres Martínez, J. F. K.

(2005), La Economía de los Celtas de la Hispania Atlántica, Vol. II. Economía, territorio y Sociedad, Serie Keltia 28, Editorial Toxosoutos, Coruña.

(2007), "Monte Bernorio en su entorno. Resumen de los trabajos arqueológicos efectuados en la Campaña de 2004", Estudios varios de Arqueología Castreña. A propósito de las exca- vaciones en los castros de Teverga (A. Fanjul, Coord.), Ayuntamiento de Teverga e Instituto de Estudios Prerromanos y de la Antigüedad, Santander, 77-101.

(2011a), El cantábrico en la Edad del Hierro. Medioambiente, economía, territorio y sociedad, Bibliotheca Archaeologica Hispana 35, Real Academia de la Historia, Madrid.

(2011b), “Una posible tésera d'hospitalidá afayadan Asturies. Les relaciones d'agospiuna Edá del fierro ente los ástures y otros pueblos célticos”, $A s$ turies, 31, 34-42.

(2014a), "Las relaciones de solidaridad y reciprocidad en la Protohistoria final europea”, Spal, $23,49-63$.

(2014b), "Estructura territorial, relaciones vecinales y gobierno de las comunidades en el norte de la Península Ibérica en la Edad del Hierro", Complutum, 25/1,177-201.

Torres Martínez, J. F. K. y Domínguez, S. D. (2008),"Monte Bernorio (Palencia): siglo I a.C. / 1936-1937 d.C. Arqueología de un campo de batalla”, Complutum, 19/2, 103-117.

Torres Martínez, J. F. K., Serna, A. y Domínguez, S. D. (2011), "El ataque y destrucción del oppidum de Monte Bernorio (Villarén, Palencia) y el establecimiento del castellum romano", $\mathrm{Ha}$ bis, 42, 127-151.

Torres Martínez, J. F. K., Martínez, A. y Pérez, C. (2012c), "Augustan campaigns in the initial phase of the Cantabrian war and roman artillery projectiles from the Monte Bernorio oppidum (Villarén, Palencia)", Archaeologisches Korrespondenzblatt, 42/4, 525-542.

(2013a), "Los proyectiles de artillería romana en el oppidum de Monte Bernorio (Villarén, Palencia) y las campañas de Augusto en la primera fase de la guerra cantábrica”, Gladius, XXXIII, 57-80.

Torres Martínez, J. F. K. y Martínez, A. (2012), Monte Bernorio. Guía de Vista Arqueológica, Col. Montaña Palentina, Palencia.

Torres Martínez, J. F. K., Martínez, A.y de Luis, S. (2012a), "El Oppidum de Monte Bernorio. Nueve siglos de Historia", Kobie, 30, 137-146.

(2012b), "Una “piedra del rayo" recuperada en el oppidum de Monte Bernorio (Villarén, Palencia). Sobre la ceraunia en la Cantabria prerromana”, Boletín del Seminario de Estudios de Arte y Arqueología, LXXVII-LXXVIII, 219-243.

Torres Martínez, J. F. K., Martínez, A. y Serna, A. 
(2013b), "El oppidum de Monte Bernorio (Villarén, Palencia). Una ciudad fortificada de la Edad del Hierro en la Montaña Palentina”, Colección de Historia de la Montaña Palentina, 7, Editorial Aruz, Palencia, 11-86.

Traina, G. (2007), «La Géographie entre Érudition et politique: Pline l'Ancien et les frontières de la connaissance du monde", La invención de una geografía de la Península Ibérica II. La época imperial (G. Cruz Andreotti, P. Le Roux, y P. Moret, Eds.), Diputación de Málaga y Casa de Velázquez, Málaga, 95-114.

Unzueta, M. (1994), "Indigenismo prerromano en la vertiente cantábrica del País Vasco: Fuentes documentales y contexto arqueológico”, Problemática de la Reconstrucción del Poblamiento en el País Vasco: Un enfoque interdisciplinar, Illunzar, 2, 101-112.

Valle, M. A. y Serna, A. (2003), "El castro de Castillnegro y otros asentamientos de la Edad del Hierro en el entorno de la Bahía de Santander", La Arqueología de la Bahía de Santander, Tomo I (C. Fernández Ibáñez y J. Ruiz Cobo, Eds.), Fundación Marcelino Botín Ed., Santander, 353-390.

Vigil M. y Barbero, A. (1974), Sobre los orígenes sociales de la Reconquista, Ed. Ariel, Barcelona.

Wells, P. S. (1988), Granjas, aldeas y ciudades: comercio y orígenes del urbanismo en la Protohistoria Europea, Editorial Labor, Barcelona.

Woolf, G. (2009), "Cruptorix and his kind. Talking ethnicity on the middle ground", Ethnic Constructs in Antiquity: The Role of Power and Tradition (T. Derks y N. Roymans, Eds.). Amsterdam University Press, Amsterdam, 207-217.

Woolf, G. (2011), Tales of the Barbarians: Ethnography and Empire in the Roman West, Wiley-Blackwell, Chichester. 